\title{
THE HISTORICAL COLLECTION OF LIVERWORTS FROM SAKHALIN BY URBIAN FAURIE (1846-1915) IN HERBARIUM OF KYOTO
}

\section{ИСТОРИЧЕСКАЯ КОЛЛЕКЦИЯ ПЕЧЕНОЧНИКОВ С САХАЛИНА В ГЕРБАРИИ КИОТО, СОБРАННАЯ УРБЕНОМ ФОРИ (1846-1915)}

\author{
VADIM A. BAKALIN ${ }^{1,2} \&$ TOMOYUKI KATAGIRI ${ }^{3}$ \\ ВАДИМ А. БАКАЛИН ${ }^{1,2}$, ТОМОЮКИ КАТАГИРИ ${ }^{3}$
}

Abstract

\begin{abstract}
The paper provides the brief sketch of the life of Father Urbian Faurie (1846-1915), the remarkable French missionary and botanist who made a great input to the understanding of bryophyte flora of Sakhalin at the primary stages of its exploration. The original specimens gathered by U. Faurie housed in KYO were re-studied. As a result, four species were newly identified from his collection, the records of two species not found in Sakhalin since the beginning of 20-th century (probably extinct in the current flora) were confirmed and an excluding of one species from the previously published lists was confirmed.
\end{abstract}

Резюме

Приводится краткий биографический очерк жизни патера Урбена Фори (1846-1915), выдающегося французского миссионера и ботаника, внесшего значительный вклад в познание бриофлоры Сахалина на ранних этапах ее изучения. Оригинальная коллекция, собранная Фори на Сахалине, была переизучена. В результате выявлено 4 вида, ранее не указывавшиеся из этой коллекции, подтверждена правильность указаний двух видов, не найденных на Сахалине после Фори (с начала 20 века) и, возможно, исчезнувших из состава флоры, и подтверждена правильность исключения одного вида, ранее указывавшегося для Сахалина, как ошибочно определенного.

KEYWORDS: Hepaticae, Sakhalin, Urbian Faurie, history of bryological researches, East Asia.

In the course of the visiting of the herbarium in Kyoto university museum (KYO) the senior author had an opportunity to study Sakhalin liverwort collection gathered by French missionary Urbain Faurie (1846-1915) the remarkable collector, who "was one of most important plant collectors in Japan" (Kakuta, 1992: 59). Faurie made a great contribution to understanding of flora of Japan, as well as Taiwan, Korea, Hawaii, Kuril Islands and Sakhalin. His interests as collector were not limited by vascular plants, but also spread to bryophytes, fungi and lichens (the latter two groups in his collections are mostly unidentified still today). The original Faurie collection is housed now in KYO, where it is arranged firstly by a group (vascular plants, mosses, hepatics, lichens, and fungi) and then by a field collection number. Total quantity of liverwort specimens collected by Faurie and housed in KYO is difficult to estimate since although they are arranged by field numbers there are numerous number omissions and, contrary, many specimens have the same number (although sometimes collected in different places within different years), and some gatherings have no number at all. Just very preliminary we may suggest that no less than 5000 liverwort specimens are housed in KYO.

U. Faurie died at the height of the First World War, the time when "the terrible war now raged over all Europe" (Hayata, 1916: 268) and no memoirs about this great botanist and missionary appeared at that time in his motherland. Due to data in hand, the only note on Father Faurie biography appeared in English is that by Hayata (1916), and then life and collecting schedule were discussed many times in Japanese (Kinashi, 1932; Hatusima, 1963, etc.) that hardly to read for Europeans. The former description (Hayata, 1916) was published almost a century ago in the series hardly available now for Russian (and also for other countries) readers. This is a very pity circumstance, because many species were described as new for science based on Faurie' collections, but only a few people know who was Urbain Faurie. To fill this gap we provide the brief sketch of his life, based mostly on Hayata (1916), Kinashi (1932) and Kitagawa (1979).

1 - Botanical Garden-Institute FEB RAS, Makovskogo Street, 142, Vladivostok, 690024, Russia - Ботанический сад-институт ДВО РАН, ул. Маковского, 142, Владивосток, 690024;

2 - Institute of Biology and Soil Science FEB RAS, Stoletiya Vladivostoka Avenue, 159, Vladivostok, 690022, Russia, Биологопочвенный институт ДВО РАН, пр. Столетия Владивостока, 159, Владивосток, 690022; e-mail: v bak@list.ru

3 - Department of Biological Science, Graduate School of Science, Hiroshima University, Kagamiyama 1- $\overline{3}-1$, Higashihiroshimashi, Hiroshima 739-8526, Japan. e-mail: tomoyuki-katagiri@hiroshima-u.ac.jp 


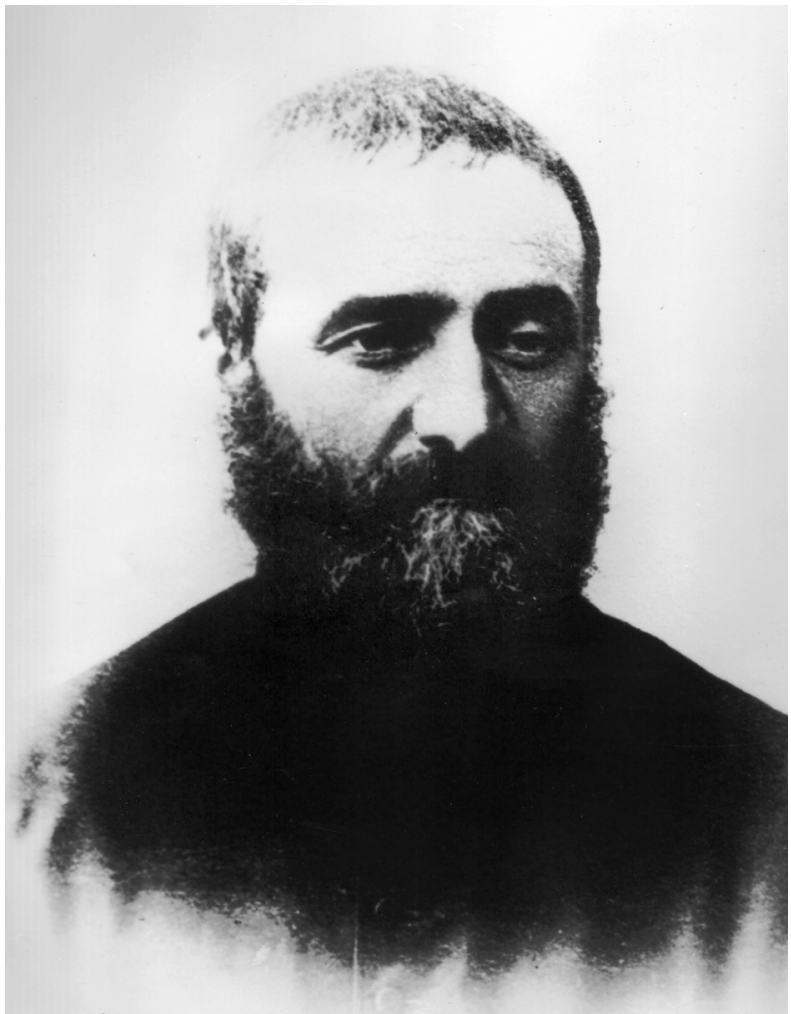

Fig. 1. Father Urbain Faurie in1906, reproduced from N. Kinashi (1932).

Urbain Faurie was born in Duniéres (Haute-Loire, France), a village located south of Lyon, on December 31, 1846 and baptized on the next day. As it was mentioned by Kinashi (1932), U. Faurie father (Cyrille Faurie) registered the birth day of U. Faurie as 1 January of 1847 that resulted in erroneous indications in subsequent literature, commonly reported U. Faurie birth year as 1947. In 1873 when he was 27 years old, he graduated from Missions Etrangères de Paris and was ordained to the priesthood. Soon after graduation, he left Paris for Japan for missionary work. In August of this year Faurie arrived to Yokohama as a catholic missionary and started a missionary work in Japan. After staying in Yokohama for 5 months, he moved to Niigata Prefecture in 1874 . During his stay in Niigata he has got a request for collecting Japanese plants from a well-known French botanist Adrien Franchet (1834-1900) who worked at the Muséum National d'Histoire Naturelle at Paris (P). After that Faurie started to collect plants in Japan and to send his specimens abroad for identification. Franchet's "Stirpes Novae vel Rariores Florae Japonicae" published in 1879 were based on Faurie's materials. Over 40 years, until his death on July 4, 1915 in Taiwan at the age of 69 , he continued making botanical collections (including tracheophytes, bryophytes, lichens, and sea weeds). His collection was gathered mainly from all over the Japanese archipelago (Ryukyu, Kyushu, Shikoku, Honshu, Hokkaido), as well as occasionally his journey in East Asia extended southwards to Taiwan, through Korea, and northwards to Sakhalin and Kurile Islands. He also col- lected in Hawaii. By the time his love to plants eclipsed other duties of his life and in the older years he devoted himself fully to a study of plants. The herbarium in Aomori, established and maintained by U. Faurie, was the largest one in Japan at the beginning of 20-th century. The noticeable personal expressions on enthusiasm and self-sacrificingness of Father Faurie in his study of plants were described by his friend Dr. B. Hayata (1916) one year later of U. Faurie' death. He wrote (p. 268): "His assiduity in the work of collecting was almost incredible. For this purpose, he travelled in all seasons. He would climb any mountain however difficult, if he thought it botanically interesting. Quite alone, with his press plates and very simple provisions on his back, he would travel and work for many days in the mountains, sleeping at night perhaps in a tree or under a crag".

The collections made by U. Faurie were distributed to various herbaria around the world and more than 700 new-for-science species have been described based on his material. One set of his collection consisting of about 60 thousands specimens was left at his hand, although that is not complete one with poor material of an early dates. After his death this collection was transferred to the herbarium of Kyoto University (KYO). Judging from his collection in $\mathrm{KYO}$, the total quantity of his specimens appears to be about five times more than an amount now present in KYO (Kakuta 1992: 59). The current status on his collection and the information on the herbaria to which he sent his collections were provided by Lanjouw $\&$ Stafleu (1957). Though a detailed itinerary of Faurie's travels was not elucidated fully, his specimen-label-based itinerary calendars were published by several authors (Sato, 1938; Horikawa 1949; Hatusima, 1963; Kakuta 1992) and they are useful for understanding his journey.

The hepatic collection of U. Faurie was identified mostly by F. Stephani, who described a huge amount of species regarded by him as new for science (Nardia fusiformis Steph., etc.). However, Stephani identified only a few specimens from Faurie' collection made in the southern Sakhalin, the land belonged to Japan since the "Treaty of Portsmouth" (which formally ended Russian-Japanese war in 1905). Due to data on the labels and Faurie' schedule compiled posthumously (Kakuta, 1992; cf. also Kitagawa, 1963), he visited Sakhalin twice, in 1907 and 1908. This Sakhalin's collection retained unattended for over than 50 years, until N. Kitagawa identified it and published in a special paper "Hepaticae of Sakhalin" (Kitagawa, 1963). This paper recorded 23 species as new for Sakhalin and confirmed some older records by other authors (for a history of Sakhalin bryophyte flora study see Bakalin et al., 2012).

By now, after many bryological researches conducted in Sakhalin and publication of a monograph "Bryoflora of Sakhalin" (Bakalin et al., 2012), the collection of Faurie has mostly a historical interest. At the same time, we were able to find four species not recorded by Kitagawa (1963) from U. Faurie' collection: Calypogeia suecica 

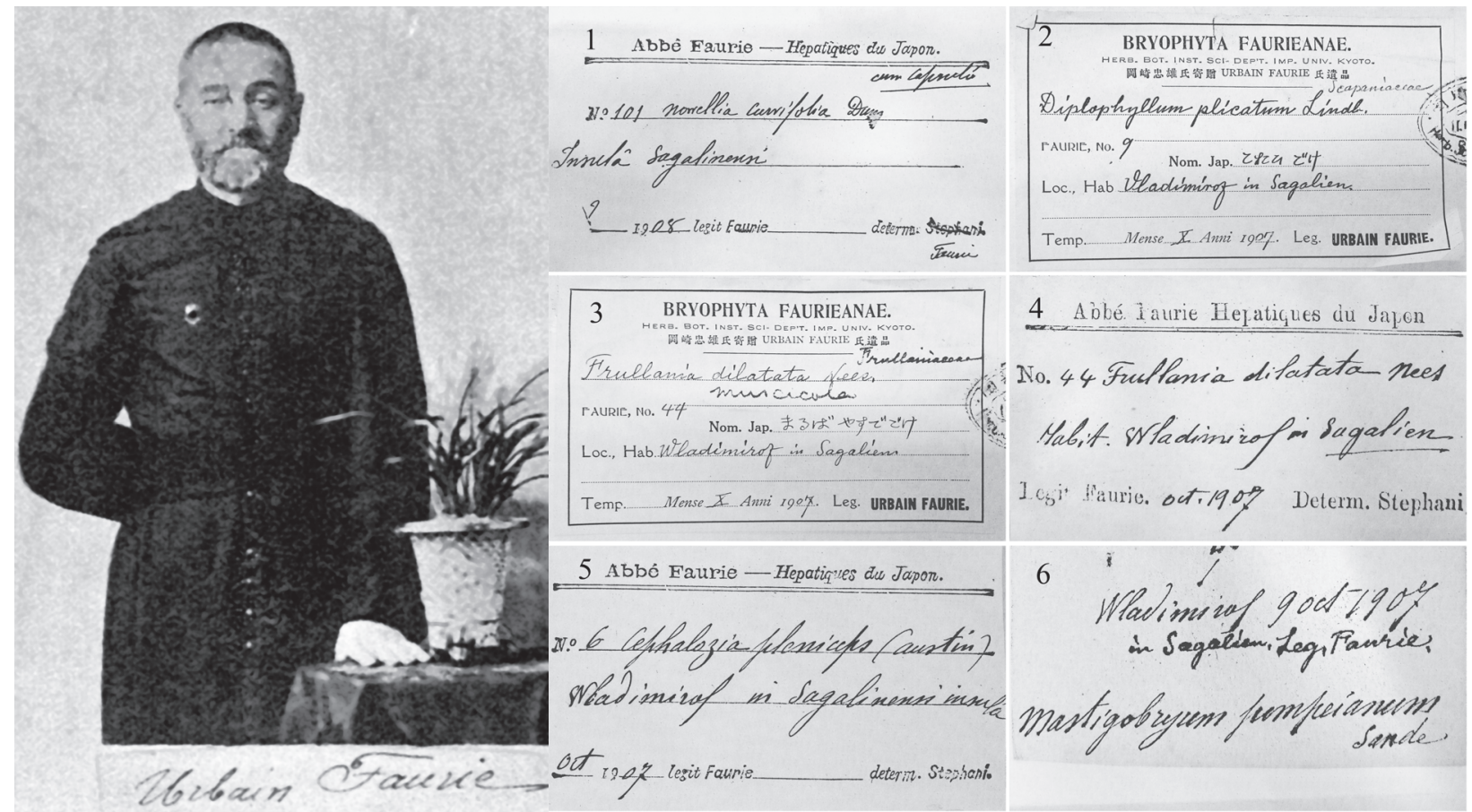

Fig. 2. U. Faurie, ca. 1910, from KYO archive.

(named as Calypogeia sp. and not published anywhere) which is rare in the Russian Far East and recorded from two localities only in Sakhalin; Radula japonica (named as Radula sp.); Radula obtusiloba (named as Radula sp.) and Frullania bolanderi (named as F. dilatata). We have also confirmed the occurrence of two species, Nowellia curvifolia and Frullania oakesiana, not found in Sakhalin since Faurie' time despite special search within recent years in the places from those they were recorded.

Also we have confirmed the occurrence of two species: Nowellia curvifolia and Frullania oakesiana, not found in Sakhalin since Faurie even despite special search within recent years in the places from those they were recorded. The latter two species growing across their areas on decaying wood and tree bark respectively, and are probably extinct from the current Sakhalin flora due to unprecedented deforestation in the course of human activity in the island within the first half of 20-th century that decreased forestry resources for 3.5 times in its southern half (Baydukova, 2012). We may suggest at the beginning of twentieth century these two species were more or less common in the southern part of Sakhalin Island because U. Faurie despite his high botanical erudition was not professional hepaticologist and collected mostly common hepatics.

The study of Faurie collection also confirmed our suggestion (Bakalin et al., 2012) on erroneous identification of 'Jungermannia pusilla' (Jens) H. Buch in Kitagawa (1963). So named specimen (n. 154) belongs to typical Solenostoma pseudopyriflorum, the recently described taxon.Below we provide the list of species found in Faurie's collection in KYO, annotated by geographic data as it is written on the label (for correlation with
Fig. 3.Original labels in U. Faurie Sakhalin collections (all from KYO). 1 - Nowellia curvifolia (Dicks.) Mitt., handwriting by Faurie; 2 - Diplophyllum plicatum Lindb. (= Macrodiplophyllum plicatum (Lindb.) H. Perss.), handwriting by Faurie; 3, 4 - Frullania dilatata Nees (misidentification of Frullania muscicola Steph.), handwriting by Faurie; 5 - Cephalozia pleniceps (Aust.) Lindb. (misidentification of Cephalozia lunulifolia (Dumort.) Dumort.), handwriting by F. Stephani(?); 6 Mastigobryum pompeanum Sande Lac. (misidentification for Bazzania trilobata (L.) S. Gray), handwriting by F. Stephani(?).

modern names see Bakalin et al., 2012), then by field collection number of Faurie and date of collection. Unfortunately we cannot refer to a herbarium barcode number in KYO since that procedure was just recently started there and did not reach bryophytes yet. Total number of specimens from Sakhalin is 56. The nomenclature follows Bakalin et al. (2012).

\section{LIST OF SPECIES}

Bazzania trilobata (L.) S. Gray - Wladimiroff, 1, 09.X.1907; 111, VI.1908; s.n., 09.X.1907.

Blepharostoma trichophyllum (L.) Dumort. var. trichophyllum - Korsakof, 163,VIII.1908;Wladimiroff, s.n., 29.VI.1908.

Calypogeia neesiana (C. Massal. et Carest) Müll. Frib. - Wladimiroff, s.n., 14.X.1907.

Calypogeia suecica (Arnell et J. Perss.) Müll. Frib. Takinosawa,s.n.,VII.1908.

Cephalozia leucantha Spruce - Korsakof, 166, VIII.1908.

Cephalozia lunulifolia (Dumort.) Dumort. Wladimiroff, 6, X.1907; 168, VII.1908; s.n., 29.VI.1908. 
Cephalozia otaruensisSteph. - Wladimiroff, 36, X.1907.

Chiloscyphus polyanthos (L.) Corda - Wladimiroff, 25, X.1907

Diplophyllum taxifolium (Wahlenb.) Dumort. Kimonai, 150, IX.1908; 152, IX.1908; Takinosawa,s.n., 24.VII.1908.

Frullania bolanderi Aust. - Kimonai prope Korsakoff, 102, IX.1908

Frullania muscicola Steph. - Wladimiroff, 44, X.1907; Korsakof, 134, 14.IX.1908

Frullania oakesiana Aust. - Kimonai, 103, IX.1908; Mereya prope Korsakof, 124,VIII.1908; 125,VIII.1908. Harpanthus flotovianus (Nees) Nees - Wladimiroff, 41, X.1907.

Lepidozia reptans (L.) Dumort. - Wladimiroff, 2, X.1907.

Liochlaena subulata (Evans) Schljak. - Wladimiroff, 384, 1907(?).

Lophozia guttulata (Lindb. et Arnell) A. Evans Korsakof, 186, 1908; Takinosawa, s.n., 24.VII.1908.

Macrodiplophyllum plicatum (Lindb.) H. Perss. -

Wladimiroff, 4, X.1907; 9, X.1907; Noriya, 141, 1908. Marsupella tubulosa Steph. - Tunaichan, 164, IX.1908; s.n., 16.IX.1908.

Mylia verrucosa Lindb. - Wladimiroff, 16, X.1907; 157, 29.VI.1908.

Nipponolejeunea subalpina (Horikawa) S. Hatt. Kimonai, 105, 23.IX.1908; s.n., IX.1908.

Nowellia curvifolia (Dicks.) Mitt. - s.d., 101, 1908;

Takinosawa, s.n., 24.VII.1908.

Plagiochila ovalifolia Mitt. - Wladimiroff, 2, X.1907;

Kimonai, 155, 21.IX.1908.

Porella fauriei (Steph.) S. Hatt. - Kimonai, 120,

21.IX.1908; s.d., s.n., 1908.

Porella grandiloba Lindb. - Wladimiroff, 2, X.1907;

3, X.1907; 7, X.1907; 8, X.1907; Kimonai 119,

21.IX.1908.

Porella gracillima Mitt. - Wladimiroff, 123, 1908.

Ptilidium pulcherrimum (G. Web.) Vain. Wladimiroff, 5, X.1907; 10, X.1907.

Radula complanata (L.) Dumort. - Wladimiroff, 17, X.1907.

Radula japonica Gottsche in Steph. - Korsakof, 163, VI.1908; 170, VI.1908.
Radula obtusiloba Steph. - Takinosawa, s.n., VII.1908

Riccardia palmata (Hedw.) Carruth. - Korsakof, 179, 20.VI.1908.

Scapania irrigua (Nees) Nees - Wladimiroff, 41, X.1907.

Solenostoma pseudopyriflorum Bakalin et Vilnet Kimonai, 154, 21.IX.1908.

\section{ACKNOWLEDGEMENTS}

Authors are deeply indebted to Dr. H. Nagamasu, curator of KYO, for the kind permission to study U. Faurie collection and providing to authors the portrait of $\mathrm{U}$. Faurie. V. Bakalin also thanks Hokkaido University Museum for financial support of his travel to KYO as the part of 'visiting professors' program maintained by the Museum, and the Russian Foundation for Basic Researches (13-04-00775).

\section{LITERATURE CITED}

[BAKALIN, VA, O.YU. PISARENKO, VYa CHERDANTSEVA, M.S. IGNATOV \& E.A. IGNATOVA] БАКАЛИН В.А., О.Ю ПИСАРЕНКО, В.Я. ЧЕРДАНЦЕВА, М.С. ИГНАТОВ, Е.А ИГНАТОВА 2012.Бриофлора Сахалина. - [Bryoflora of Sakhalin] Владивосток, Изд-во Морского госуниверситета [Vladivostok, Izd-voMorskogo gosuniversiteta], 310pp

[BAYDUKOVA, E.В.] БАЙДУКОВА Э.Б. 2012. История японского поселения Амбецу на острове Сахалин. - [History of Ambetsu Japanese Settlement on the Sakhalin Island] History-cultural researches 2(2): 9-15.

FRANCHET, A. 1879. Stirpes Novae vel Rariores Florae Japonicae. Bulletin de la SociétéBotanique de France26: 82-90.

HATUSIMA, S. 1963. A short article of Faurie's collecting travel in Japan. - Natural Science and Museums 30: 10-14. (in Japanese)

HAYATA, B. 1916. Pére Urbain Faurie. - Bot. Mag. (Tokyo)30: 267-273.

HORIKAWA, Y. 1949. The records of U. Faurie's collecting travel. -Seibutugakukaishi1: 30-33. (inJapanese)

KAKUTA, M. 1992. Abbé Urbain Faurie and its itinerary calendar of his plant hunting. - ActaPhytotax. Geobot.43: 59-74. (in Japanese)

KINASHI, N. 1932. The great collector of Japanese plants, Urbain Faurie. - ActaPhytotax.Geobot.1: 315-321. (in Japanese)

KITAGAWA, N. 1963. Hepaticae of Sakhalin. - Acta Phytotax. Geobot.19(4-6): 146-152.

KITAGAWA, N. 1979. Literature on Urbain Faurie. -Acta Phytotax.Geobot.30: 93-98. (in Japanese)

LANJOUW, J. \& F.A. STAFLEU. 1957. Index herbariorum Part II (2) Collectors E-H. - Regnum Veg. 9: 175-295.

SATO, M. 1938. Records of U. Faurie's collecting travel. - J. Jap. Bot 14: 699-701. (in Japanese) 